DOI 10.15407/mics2020.11.303

УДК 94(477.46)

\title{
Валерій Ластовський,
}

доктор історичних наук, професор

Київський національний університет культури і мистецтв

lastov@ukr.net

https://orcid.org/0000-0001-8900-5569

\section{«КОЗАЦЬКІ НЕКРОПОЛІ》 СТАРОЇ ЧЕРКАЩИНИ ТА ЇХ МІФОЛОГІЗАЦІЯ}

У статті розглянуто питання процесу міфологізації історичного минулого шляхом використання народної пам'яті. Одним із об'єктів міфологізації стали некрополі. На сьогодні некрополів старої Черкащини майже не залишилося. Про деякі з них серед населення і науковців склалися стійкі уявлення як про реальні. Насамперед їх пов'язують із історією українського козацтва. Але найвідоміші «козацькі некрополі» насправді не існували. Це стосується поховань у Трахтемирові та Каневі. У першому розташовані переважно поховання XIX століття, які не є козацькими. «Козацького некрополя» у Каневі також ніколи не було. Традиційно вважають, що тут були поховані Іван Підкова, Яків Шах, Самійло Кішка та інші козаки. Однак це міф, створений істориками і народними уявленнями. Своєрідним прикладом некрополя старої Черкащини можна вважати поховання святого Макарія Токаревського, убитого у 1678 р. під час захоплення Канева турецькими військами. Також особливим $є$ поховання Богдана Хмельницького у Суботові, адже до сьогодні відоме лише його місце знаходження, а от самої могили наразі не знайдено. Потрібно зауважити, що народні уявлення є достатньо приблизними і не дають історичній науці точної і достовірної інформації.

Ключові слова: некрополь, Черкащина, Черкаси, Канів, козацтво, козацьке літописання, монастир, історична пам'ять, міфологізація. 

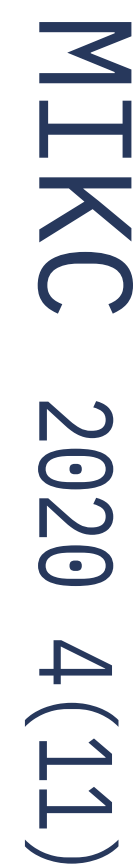

1 Ластовський, В., \& Ластовська, 0 (2002). Некрополь старої Черкащини: проблеми наукового пошуку. Наукові записки. 36. праиь молодих вчених ma acniранmiв, 9, 261-267; Куштан, Д. (2011). Некрополь з кам'яними надгробками XIX - поч. XX ст. у с. Луківка на Черкащині. В Нові дослідження пам'яток козацької доби в Україні (Випуск 20, с. 124-130). Київ; Куштан, Д. (2012). Кам'яні хрести Черкащини. В Нові дослідження пам'яток козацької доби в Україні (Випуск 21, частина 1, с. 191-197). Київ.
Історія як наука, пов’язана із вивченням минулого, завжди орієнтується на вивчення діяльності людей, які померли. Правду кажучи, померлі завжди є певним мірилом сучасності. Це стосується не лише науковців і їнього бачення історичних процесів, а й свідомості та уявлень звичайних людей. Діяльність померлих може бути виправданням або ж застереженням для живих. Тому їх цитують, вони є прикладом (морально-етичним, естетичним тощо) або ж їх засуджують, і в такому разі створюється бар'єр для поведінки сучасників і наступних поколінь. Разом 3 тим, пам'ять про померлих є одним із засобів управлінського та політичного впливу на суспільство. Будь-яка влада (державна релігійна, партійна) намагається використовувати це у своїх інтересах. Найбільш яскравим і повчальним прикладом такого підходу були часи існування СРСР.

Важливу роль у формуванні та підтримуванні у певному напрямі історичної пам'яті відіграє академічний рівень знань, якому, однак, доволі часто протистояла народна пам'ять. Інформація, яка передається через народну пам'ять, не завжди відповідає історичній реальності, а найчастіше відбиває і1і досить розмито, підкреслюючи якусь героїчну чи драматичну сторону життя. Унаслідок формується система уявлень, яка сприймається не лише населенням певного краю чи всієї країни, а й фахівцями-істориками. Натомість критичний підхід може вказувати i на зовсім інші сторони суспільних відносин, пов'язані із маніпуляціями суспільною свідомістю. Зокрема це стосується некрополів та уявлень про них.

Некрополі старої Черкащини майже не опинялися в центрі уваги науковців, на відміну від старих некрополів в інших регіонах України, яким присвячували монографічні дослідження i наукові конференції. Однак деякі спроби здійснювалися і в цьому напрямі ${ }^{1}$

Черкащина як регіон почала розвиватися фактично із другої половини XIV ст., коли тут з'явилися Черкаси спочатку у формі прикордонного посту, а потім вже й у вигляді міста на рубежі XV-XVI ст. Особливості цього регіону сформувалися і закріпилися наприкінці XV - впродовж XVI ст. завдяки колонізаційним процесам, що йшли 3 інших регіонів України (передовсім із Київщини) та появі тут у цей самий період такого соціального явища, як українське козацтво. Хоча сам термін «Черкащина» зародився у XIX ст. (зокрема фіксуємо його у 1864 р.), потім він почав поширюватися із початком XX ст. у періодичній пресі (наприклад, у газеті «Рада»), а в науковому дискурсі з'явився фактично у 1920-х (разом із публікаціями О. Олександріва та Ф. Савченка про Тараса Шевченка). 

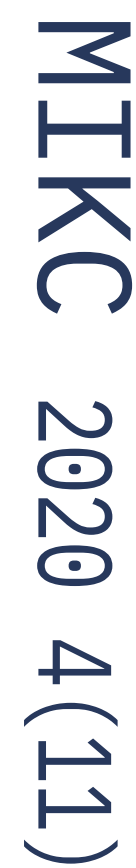

2 Александрович, М. (1860). Из Канева в Чигирин и обратно: путевые записки. Чернигов.
Багата історія цього краю передбачає начебто і наявність значних некрополів, передовсім пов'язаних 3 історією українського козацтва. Проте насправді маємо зворотну картину. До певної міри, можна стверджувати, що фактичний матеріал суперечить історичному. Адже від усього раннього періоду формування Черкащини до нас не дійшло жодного реального поховання. Ми не знаємо історичних поховань від XIV і до майже кінця XVIII ст. Натомість відомо про багатьох історичних осіб, які померли і були поховані в межах старої Черкащини, однак їхні могили не збереглися. Хоча у випадку із Богданом та Тимошем Хмельницькими маємо зворотне: місце поховання, але не їхні могили.

Попри всю легендарність «козацького краю» маємо зазначити, що реальних пам'яток відповідного часу збереглося небагато. I насамперед це стосується козацьких поховань. Першими осередками козацтва називають Черкаси і Канів. Це підтверджують документальні джерела, які фіксують проживання у цих містах великої кількості представників козацтва у XVI-XVII ст. С документальна інформація і про померлих та загиблих, однак їхніх могил немає. Можемо спиратися хіба що на народні перекази, які, звісно, не гарантують історичну точність. Про те, як місцеві жителі ставилися у XIX ст. до історичного минулого, красномовно свідчить діалог із записів етнографа та письменника Митрофана Александровича (18371881), почутий у Чигирині у 1857 р.:

«Утром я вышел погулять, с намерением узнать местные предания. Это казалось тем удобнее, что я мог, не поражая своим вопросом, спросить, зачем поставлен крест на горе. Мне отвечали: “Се Хмильницкого гора; на ий и замок його був.

- Що ж то за Хмильницкий?

- А хто його знае; князь чи пан якийс...."» ${ }^{2}$.

На формування історичної пам'яті впливають суспільні структури, зокрема церковні інститути, які відрізняються найбільшою сталістю серед останніх. У нашому випадку це ми бачимо на прикладі того ж таки канівського пантеону.

У цьому контексті особливим похованням слід вважати некрополь святого Макарія Токаревського, вбитого у 1678 р.: це рака 3 мощами канівського архімандрита, перевезена із Переяслава в Черкаси у 1942 р., нині зберігається у кафедральному Свято-Михайлівському соборі. Від кінця XVII ст. останки цього святого великомученика постійно зберігалися у Переяславі. I про це поховання та про збереження пам'яті про Макарія піклувалася саме Церква.

Стара Черкащина в уяві великої частини науковців, краєзнавців і пересічних громадян - це своєрідний пантеон героїв епохи козач- 

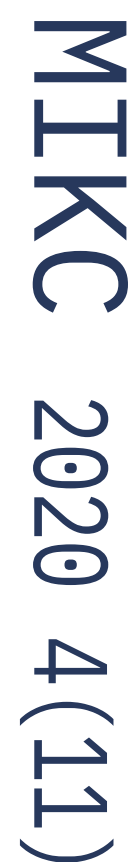

3 Горенко, Л. (1992). Чигиринський Троїцький жіночий монастир. Родовід, 4 59-66. чини. На жаль, без реальних їхніх могил. Не збереглися, наприклад, поховання Криштофа Косинського, загиблого в Черкасах у 1593 р.; могили козаків, що полягли у битві під Корсунем; і навіть могили тих козаків, які мешкали у Черкасах у XVI-XVII ст. і померли від старості або хвороб. Немає інформації навіть про можливе місцезнаходження цих могил.

Разом $з$ тим, є більш-менш точні матеріали про «козацькі некрополі». Наприклад, Л. Горенко зазначає, що Троїцький Чигиринський монастир «був фамільним роду гетьмана Дорошенка», в ньому були поховані члени родини (Андрій Дорошенко, Василь Дорошенко та ін.). Однак, на жаль, уже у 1920-х рр. поховань тут не було ${ }^{3}$.

Зауважимо, що серед багатьох науковців і краєзнавців досить поширеним є використання терміна «козацькі монастирі». Фактично, так називають чи не всі чоловічі чернечі осередки, як діяли у XVI-XVIII ст. Як правило, досить безапеляційно, але водночас i бездоказово, стверджують, що в цих монастирях проживали або переховувалися козаки. Ідеться, зокрема, про Трахтемирівський, Канівський, Мотронинський, Корсунський, Мошногірський, Медведівський монастирі.

Безперечно, козацтво мало відносини із монастирями. Частина 3 цих обителей перебувала під опікою окремих представників старшини, наприклад, уже згадуваному Чи- гиринському монастирю допомагала родина Дорошенків, про Корсунський монастир дбав Григорій Гуляницький тощо. Безперечно, козацтво робило свій внесок в утримання і будівництво монастирів. Однак, на нашу думку, це не дає підстав уживати термін «козацькі монастирі», позаяк внесок представників шляхти і селянства у підтримування чернецтва був також значним. Використання поняття «козацький монастир» саме у науковому просторі є недопустимим, оскільки це спотворює загальний історичний контекст і реальні історичні процеси. Будь-який монастир можна розглядати лише 3 погляду його належності до певної конфесії та соціально-політичної ситуації навколо неї. Утім, це питання має бути предметом окремого дослідження.

Що ж до «козацьких некрополів», то їх усе ж таки прив'язують саме до церковних осередків (наголосимо: небезпідставно!). I часто навколо них створюється свій певний «козацький міф». Найяскравішим міфічним пантеоном стали Канів і Трахтемирів - два населені пункти, у якими, за легендами, були розташовані найперші легендарні козацькі поховання. У Каневі, за деякими твердженнями, у XVI - на початку XVII ст. були поховані особи, що уособлювали героїчне минуле, - Остафій Дашкович, Іван Підкова, Яків Шах, Самійло Кішка. А Трахтемирів сьогод- 

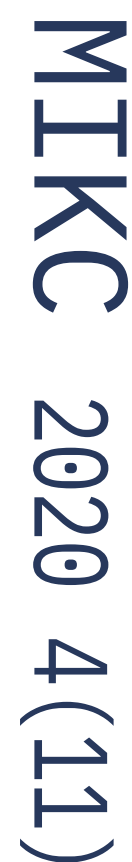

4 Лimonuc гадяцького полковника Григорія Грабянки. (1992). Київ, 27.

5 История русов. (1846). Москва, 31.

6 Історія міст і сіл Украӥнськоӥ РСР. Черкаська область. (1972). Київ, 324325.

7 Величко, С. (1864). Летопись событий югозападной России в XVII веке (Том 4, c. 156). Приложения). Киев. ні вважають чи не найголовнішим місцем поклоніння козацькому минулому (завдяки міфу про козацький Трахтемирівський монастир).

Міф почав творитися на початку XVIII ст., а потім набув поширення у пізнішій історіографії. У відомому «Літописі» гадяцького полковника Григорія Грабянки (до 1666 - бл. 1738) згадано про Івана Підкову: «...Після страти тіло його взяли побратими і поховали в монастирі у Каневі» ${ }^{4}$. На початку XIX ст. до творення цього міфу долучився автор «Історії русів», написавши про Якова Шаха: «Король польский... предал гетмана суду... Он был отрешен от гетманства и осужден на вечное заточение в монастырь Каневский, где по воле его посвящен в монахи и кончил жизнь свою спокойно в монашестве» ${ }^{5}$. Наведемо також характерну цитату із пізнішої історіографії: «...десь 3 цих часів Канів став своєрідною козацькою святинею. Літні запорожці, що вже не могли брати участі в походах і боях, почали селитися та доживали віку на Чернечій горі, неподалік канівського монастиря» ${ }^{6}$.

Безумовно, в кожній історіографічній ситуації підживлювання цього міфу було пов'язане із певними ідеологічними моментами. Для козацького літописання, зрозуміло, було важливим підтримання ідеї лицарського героїзму. Для науки імперської епохи вже більш знаковим було висвітлення героїзму в контексті боротьби із католицької Річчю Посполитою. Для історіографії радянського періоду вагомим аргументом було використання козацького пантеону для підтримання теорії класової боротьби. А сьогодні для українського суспільства важливим стає відображення національної боротьби в контексті державотворення.

Відповідно до цього «козацького міфу», Іван Підкова, Яків Шах і Самійло Кішка були поховані в Успенському Канівському монастирі наприкінці XVI - на початку XVII ст. Тут треба зазначити, що спершу про Самійла Кішку не йшлося, про нього згадали в літературі дещо пізніше. Підставою для цього стали два твори - записи середини XVII ст. польського хроніста Мацея (Тимофія/Матвія) Титловського (Титлевського) та народна пісня «Дума про Самійла Кішку».

Записи Мацея Титловського у 1770 р. переклав із польської мови канцелярист Генеральної військової канцелярії Степан Лукомський (1701-1779). Потім їх було опубліковано у додатках до літопису Самійла Величка у 1864 р. Там, зокрема, були такі слова: «...гетман Кошка в городе украинском Каневе погребен, чего в доказательство там его гроб свидетельствует» ${ }^{7}$. Про цей факт зазначив також Д. Яворницький у другому томі своєї праці «Історія запорозьких коза- 
8 Кулиш, П. (1874). История воссоединения Руси (Том I, с. 355). Санкт-Петербург .

9 Науменко, В. (1883). Происхождение малорусской думы о Самуиле Кошке. Киевская старина, 6, 212-232.

10 щербак, В. (2011). Підкова Іван. В Енциклопедія історї̈ України (Том 8, с. 236). Київ.

11 Лепявко, С. (2013). Шах Яків. В Енииклопедія історії України (Том 10, с. 599). Київ.

12 Голобуцький, П. (20๑7). Кішка Самійло. В Енииклопедія історії ків». Однак в історичній науці наведено й іншу думку: про загибель Самійла Кішки за 18 років до тих подій, які описував Мацей Титловський.

Щодо «Думи про Самійла Кішку», то там написано: «Правда, панове, полягла / Кішки Самійла голова, / В Києво-Каневі манастиpi»» ${ }^{8}$. Звернемо увагу на два моменти: 1$)$ думу про Самійла Кішку було складено, найімовірніше, після середини XVII ст., що стверджував ще В. Науменко у 1883 р..$^{9}$ 2) слова «в Києво-Каневі манастирі» містять доволі розмиту вказівку щодо місця поховання.

Зауважимо, що відомі історики П. Куліш, Д. Яворницький, А. Стороженко та інші стверджували, що Самійла Кішку могли поховати у Києві у церкві Миколи Доброго, яку він начебто збудував.

Однак якщо проаналізуємо реальні факти, а саме місце загибелі кожного із згаданих вище козацьких ватажків, то побачимо таку картину:

- Івана Підкову стратила польська влада у Львові 16 червня 1578 р. ${ }^{10}$;

- Яків Шах загинув у бою за місто Ясси в березні 1578 р. ${ }^{11}$;

- Самійло Кішка загинув у битві за естонське місто Вільянді (колишнє Феллін) 16 травня 1602 p. $^{12}$

Уже навіть перелік пунктів, де загинули козацькі ватажки, становить широку геогра- фічну палітру, охоплюючи всю Східну Європу. I з огляду на це важко уявити, у який спосіб загиблих можна було привезти і поховати в одному місці, до якого, до слова, ніхто 3 них не мав жодного стосунку. Канів наприкінці XVI ст. не був ані козацьким, ані релігійним центром. До того ж це місто перебувало під контролем польської влади. Чи дала б вона можливість формувати тут козацький пантеон із тих осіб, які не належали до владної еліти? А Івана Підкову польська влада взагалі вважала злочинцем.

Та й Канівського монастиря на ті часи ще не існувало. Його було започатковано у 1620-х. Тож поширена думка, що Канівський монастир у XVI ст. був одним із осередків українського козацтва (про це, зокрема, згадано у працях Г. Грабянки, автора «Історії русів», Л. Похілевича, М. Максимовича та ін.), не має жодного підтвердження в історичних джерелах.

Мовчить про це й народна пам'ять, принаймні, ми не знаємо легенд або переказів, де б це хоч якимось чином зачіпалося.

Можемо лише висловити таке припущення. На початку XVIII ст. розпочалося формування героїчного образу канівського архімандрита Макарія Токаревського, який загинув під час нападу татарського загону у 1678 р. на Канів. У 1688 р. його мощі знайшли і перенесли до Переяслава. У 1700-1701 pp. 


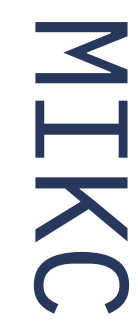

$\infty$
$\infty$
0

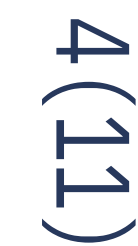

13 Ластовський, В. (20๑8). Між суспільством $i$ державою. Православна черква

в Україні наприкіниі XVII -

y XVIII столітmi в iсторї̈ та

історіографії. Київ, 124 було сформовано Переяславську єпископію як вікаріатство Київської митрополії, яка у 1733 р. перетворюється вже на самостійну єпархію. Особливістю цієї єпархії упродовж усієї історії було поширення іiі претензій на території Правобережної України, що в цей час перебували під владою Речі Посполитої.

Творення образу преподобномученика Макарія Токаревського відбувалося під безпосереднім керівництвом переяславського єпископа Захарія Корніловича, який походив із козацької родини (його дід був переяславським сотником). Його ж вважають першим творцем «Житія» св. Макарія. За розпорядженням Корніловича мощі святого у 1713 р. були розміщені у кафедральному Михайлівському Переяславському монастирі. Потрібно також зазначити, що є документальне свідчення про те, що він іменував себе ігуменом трахтемирівським і канівським ${ }^{13}$. Фактично Канів і його околиці на початку XVIII ст. стали для Переяславської єпархії плацдармом для подальшого поширення своєї влади на Правобережжі. Тож цілком можливо, що канівська легенда про козацький пантеон поширилася із церковного середовища Переяславської єпархії на початку XVIII ст. У такий спосіб, по-перше, зміцнювався авторитет Переяславської єпарxiї i, по-друге, закріплювалося право єпархії на території Канева та його околиць. Далі цю історію підхопили козацькі літописці й розширили іiі за рахунок власних героїв. Хоча навряд чи такий підхід можна вважати реалізацією якоїсь політичної концепції.

Звісно, може постати запитання: чому саме Канів став центром «козацького міфу», а не Трахтемирів? Напевно, тому, що, по-перше, з Каневом уже була пов'язана героїчна історія Макарія Токаревського, по-друге, на Канів, хоч і дуже приблизно, але все ж таки вказувала дума про Самійла Кішку, по-третє, через дату смерті Івана Підкови. Щодо останнього факту, то «Postanowienie z Niżowcy» (документ щодо взяття козаків на службу до Стефана Баторія, після якого Трахтемирів було визначено базою для козацтва) король підписав у Львові 16 вересня 1578 р., а Іван Підкова загинув 16 червня 1578 р. Суперечність $є$ цілком очевидною навіть для творців міфології. Водночас, звернемо увагу на два моменти у «Літописі» Самійла Величка (1670-1728). По-перше, це достатньо красномовний опис погрому Канева у 1678 р. «...багато канівських людей втекло й замкнулося тоді у велику кам'яну церкву старого й красного Канівського монастиря, але турки, достатньо обклавши ту церкву навколо дровами й соломою, запалили іiі разом 3 усім тим монастирем і всіх людей у церкві задушили». По-друге, це вказівка на переговори між владою Речі Посполитої та гетьманом 
14 Величко, С. (1991). Лimonuc (Том 2, с. 127,245$)$. Київ.

15 Куштан, Д. Кам'яні хрести Черкащини, 191-197.
Петром Дорошенком у 1670 р., під час яких обговорювався проект створення у Каневі резиденції «запорозького гетьмана» ${ }^{14}$.

Зауважимо, що всіх осіб у «канівському пантеоні» об'єднує одне - їхні героїзм і жертовність у боротьбі з Кримським ханатом i Османською імперією. Наприкінці XVII - на початку XVIII ст. це була цілком очевидна загроза у міжнародних відносинах, протистояння якій об'єднувало весь європейський континент.

Що ж до поховання Остафія Дашковича в Каневі, то це вже витвір фантазії сучасних черкаських краєзнавців. Старосту черкаського і канівського початку XVI ст. досить часто пов'язують із зародженням українського козацтва, інколи навіть називають його засновником і першим гетьманом. Для істориків давно відомо, що місце його поховання Успенський собор Києво-Печерської лаври. До 1970-х рр. на території цієї пам'ятки була надмогильна плита із іменем Остафія Дашковича. На жаль, вона зникла, і до сьогодні місце ії перебування невідоме.

Перейдемо до трахтемирівської козацької міфології. Творення останньої також багато чим завдячує Григорію Грабянці, котрий ввів у український науковий обіг, витлумачуючи на свій лад польських письменників, міф про те, що польський король Стефан Ба- торій подарував реєстровому козацтву Трахтемирівський монастир. Проте, оминаючи розгляд самого цього питання, зупинимося лише на одному із його наслідків.

На сьогодні у науковій літературі, краєзнавчих розвідках та на обивательському рівні побутує дуже стійкий стереотип, що у Трахтемирові зберігся справжній давній козацький цвинтар, на якому розташовані кам'яні надгробки на козацьких могилах хрести та обеліски.

Цвинтар і справді там є, однак, як свідчать сучасні дослідження, до козацтва не має жодного стосунку ${ }^{15}$. Сдине, що вказує на можливість поховань козаків у Трахтемирові, - це інформація Лаврентія Похілевича, опублікована у 1864 р., про наявність тут могили із кам'яним хрестом та написом на ньому, в якій був похований у 1652 р. козак Війська Запорозького Іван Муха. Однак ми можемо згадати про поховання козаків у багатьох інших населених пунктах України, де вони проживали і помирали, але не залишали по собі кам'яних хрестів. У будь-якому випадку, немає підстав говорити про «козацький некрополь» у Трахтемирові. До слова, у цьому місті й досі стоїть кам'яний хрест, начебто на могила Івана Мухи, однак на ньому немає жодних написів, які б могли свідчити про час його створення або про 
16 Літопис гадяцького полковника Григорія Грабянки, 132.

17 Лазуренко, В. (2019). у пошуках крипти великого державотвория України Богдана Хмельницького. Поховання гетьмана України Богдана Хмельнииького в Іллінській иеркві у с. Суботів: від столітніх досліджень, легенд та міфів до сучасних наукових гіпотез. Черкаси.

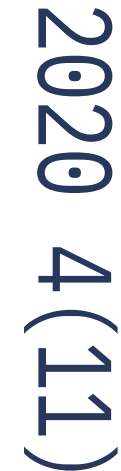

його належність. Ба більше, нещодавні археологічні дослідження показали, що там розміщене жіноче поховання.

Одне з останніх повідомлень, пов'язаних iз некрополями Черкащини та трансформацією уявлень про них, стосується усипальниці Богдана Хмельницького у Суботові та пам'яті про неї. Донедавна доволі поширеною була думка, що у 1664 р. польський шляхтич Стефан Чарнецький (1599-1665) спалив Суботів і зруйнував могили Богдана Хмельницького і його сина Тимоша. Вперше цей переказ з'явилася у козацькому літописанні XVIII ст., зокрема у «Літописі» вже згаданого гадяцького полковника Григорія Грабянки та у т. зв. Чернігівському літописі, а потім побутувала у кількох різних варіантах. I хоч дослідники вже давно вважали ці дані неправдивими (наприклад, Іван Крип'якевич), тим не менше, легенда продовжувала існувати в науковій літературі, не кажучи вже про народні уявлення. Григорій Грабянка так описував цю подію: «... Чернецький спалив Бужин та Суботів, а тіла Богдана Хмельницького та його сина Тимоша повикидав 3 домовин» ${ }^{16}$

Однак науковці продовжували досліджувати історію поховання Богдана Хмельницького. 3 цією метою неодноразово організовували експедиції на Чигиринщину. В липні 2019 р. було проведено спеціальну конферен- цію «Усипальниця гетьмана Богдана Хмельницького: історія, міфи, сучасний стан». Того ж року побачила світ книжка черкаського історика Валентина Лазуренка, присвячена пошукам відповідей на питання про загадку поховання Богдана Хмельницького ${ }^{17}$.

3 квітня 2020 р. історик Тарас Чухліб через соціальні мережі повідомив (посилаючись на текст оригінального листа С. Чарнецького, виявленого у Варшавському архіві давніх актів), що «сам польський гетьман Стефан Чарнецький нічого не згадує про цю трагічну для нас подію у своїх листах-звітах до короля за 1664 рік. Ротмістр Ян Флоріан Дробиш-Тушинський, що був у війську Чарнецького, яке плюндрувало Правобережну Україну написав: "Рік 1664... Король пішов до Польщі, а ми на ту сторону Дніпра $з$ паном Чарнецьким перейшли. Ціле літо військо добувало міст в Україні Ставища, Лисянку та інші”. Очевидець пише про розстріл Івана Виговського у тому ж році, але нічого про напад на Суботів і викинення праху Богдана Хмельницького! Якби це насправді відбулося, хіба б це не занотував сучасник? Нічого немає про цю подію і в записах інших сучасників - "Клімактерах" Веспасіана Коховського і щоденникових записах ще одного очевидця тих подій Міколая Йеміловського...».

Отже, можемо стверджувати, що історична пам'ять щодо некрополів старої Чер- 
кащини багато в чому формується під впливом міфологізації минулого, що відбувалася переважно у XVIII ст., а закріплювалася у XIX-XX ст. Цей процес охоплює майже вс верстви населення - від науковців і управлінців до пересічних громадян. Звісно, процес міфологізації спирається передовсім на певні ідеологічні основи, властиві кожному історіографічному напряму. Завдяки цьому формувався і вплив на уявлення населення. Потрібно визнати, що створені історіографічні міфи є надзвичайно стійкими. 3'ясування ж реальної історичної ситуації потребує серйозних наукових досліджень водночас подолання стереотипів.

\section{References}

Aleksandrovich, M. (1860). Iz Kaneva $v$ Chigirin $i$ obratno: putevyie zapiski. Chernigov [in Russian].

Holobutskyi, P. (2007). Kishka Samiilo. In Entsyklopediia istorii Ukrainy (Vol. 4, p. 341). Kyiv [in Ukrainian].

Horenko, L. (1992). Chyhyrynskyi Troitskyi zhinochyi monastyr. Rodovid, 4, 59-66 [in Ukrainian]

Istoriia mist $i$ sil Ukrainskoi RSR. Cherkaska oblast.

(1972). Kyiv [in Ukrainian].

Istoriya rusov. (1846). Moskva [in Russian].

Kulish, P. (1874). Istoriya vossoedineniya Rusi (Vol. I). Sankt-Peterburg [in Russian].
Kushtan, D. (2011). Nekropol z kamianymy nadhrobkamy XIX - poch. XX st. u s. Lukivka na Cherkashchyni. In Novi doslidzhennia pamiatok kozatskoi doby $v$ Ukraini (Vol. 20, pp. 124-130). Kyiv [in Ukrainian].

Kushtan, D. (2012). Kamiani khresty Cherkashchyny. In Novi doslidzhennia pamiatok kozatskoi doby v Ukraini (Vol. 21 (1), pp. 191-197). Kyiv [in Ukrainian].

Lastovskyi, V. (2008). Mizh suspilstvom $i$ derzhavoiu. Pravoslavna tserkva v Ukraini naprykintsi XVII $-u$ XVIII stolitti $v$ istorii ta istoriohrafii. Kyiv [in Ukrainian].

Lastovskyi, V., \& Lastovska, O. (2002). Nekropol staroi Cherkashchyny: problemy naukovoho poshuku. Naukovi zapysky. Zb. prats molodykh vchenykh ta aspirantiv, 9, 261-267 [in Ukrainian].

Lazurenko, V. (2019). U poshukakh krypty velykoho derzhavotvortsia Ukrainy Bohdana Khmelnytskoho. Pokhovannia hetmana Ukrainy Bohdana Khmelnytskoho v Illinskii tserkvi u s. Subotiv: vid stolitnikh doslidzhen, lehend ta mifiv do suchasnykh naukovykh hipotez. Cherkasy [in Ukrainian].

Lepiavko, S. (2013). Shakh Yakiv. In Entsyklopediia istorii Ukrainy (Vol. 10, p. 599). Kyiv [in Ukrainian].

Litopys hadiatskoho polkovnyka Hryhoriia Hrabianky. (1992). Kyiv [in Ukrainian].

Naumenko, V. (1883). Proishozhdenie malorusskoy dumyi o Samuile Koshke. Kievskaya starina, 6, 212-232 [in Russian].

Shcherbak, V. (2011). Pidkova Ivan. In Entsyklopediia istorii Ukrainy (Vol. 8, p. 236). Kyiv [in Ukrainian]. Velichko, S. (1864). Letopis sobyitiy yugozapadnoy Rossii v XVII veke (Vol. 4). Kiev [in Russian]

Velychko, S. (1991). Litopys (Vol. 2). Kyiv [in Ukrainian] 


\section{Valerii Lastovskyi \\ COSSACK CEMETERIES OF THE OLD CHERKASH REGION AND THEIR MYTHOLOGIZATION}

The article considers the process of mythologizing the historical past through the use of folk memory. Necropolises became one of the objects of mythologizing. Today there are almost no necropolises of the old Cherkasy region left. Among the most significant of them is the tomb of Bohdan Khmelnytsky and his son. Some of the necropolises among the population and among scientists have developed stable ideas as real. First of all, they are connected with the history of the Ukrainian Cossacks. But the most famous Cossack necropolises did not really exist. This applies to burials in Trakhtemir and Kaniv. In the first are mostly burials of the XIX century, which are not Cossack. There was never a Cossack necropolis in Kaniv. It is traditionally believed that Ivan Pidkova, Yakiv Shah, Samiylo Kishka and other Cossacks were buried here. But in fact it is a myth created by historians and popular beliefs. A peculiar example of the necropolis of the old Cherkasy region is the burial of St. Macarius Tokarevsky, who was killed in 1678 during the capture of Kaniv by Turkish troops. The burial of Bohdan Khmelnytsky in Subotov should also be considered special. After all, only his whereabouts are known to this day, but the grave itself has not been found yet. It should be noted that folk ideas are quite approximate and do not give historical science accurate and reliable information.

Keywords: necropolis, Cherkasy region, Cherkasy, Kaniv, Cossacks, Cossack chronicle, monastery, historical memory, mythologizing. 